\title{
Seasonal fluctuations in the size spectra, biochemical composition and nutritive value of the seston available to a suspension-feeding bivalve in a subarctic environment
}

\author{
J. M. Navarro*, R. J. Thompson** \\ Ocean Sciences Centre, Mernorial University of Newfoundland, St. John's, Newfoundland, Canada A1C 5S7
}

\begin{abstract}
Seasonal changes in the size spectrum and biochemical composition of the suspended particulate matter were recorded for 2 yr in Logy Bay, southeast Newfoundland, Canada. The seston load was lower than in many shallow marine bays, owing partly to a relatively small terrigenous input and little silt, and the quantity of the particulate organic matter primarily depended on phytoplankton productivity. The ratio chlorophyll a:phaeopigments was high during the phytoplankton bloom, due to the living nature of the organic seston at this time, compared with the rest of the year, when lower values were associated with the highly degraded suspended material The size-frequency distribution of the suspended particulate matter reflected the succession of the phytoplankton community throughout the year. The spnng peaks were composed mainly of single diatoms and chain-forming diatoms in the size range 20 to $60 \mu \mathrm{m}$ (equivalent spherical diameter). Variations in carbohydrate, lipid and protein in the seston were primarily associated with the periods of high and low standing stocks of phytoplankton observed in this environment. The seasonal trends were very similar for each biochemical component, and values were highly correlated with those for other properties of the seston, such as organic matter, chlorophyll $a$ and particulate organic carbon and nitrogen. The nutritional quality of the seston was expressed by a food index, calculated as the ratio of food material (protein + carbohydrate + lipid) to total seston. This index followed the cycle of the phytoplankton bloom, with maximum values during spring and summer, and much lower values during winter. The results suggest that the gross analysis of the suspended particulate matter or the measurement of a single chemical variable cannot describe fully the nutritive value of the seston to a suspension-feeder. An analysis of the size spectrum and biochemical composition of the material is required for this purpose.
\end{abstract}

KEY WORDS: Seston · Phytoplankton bloom · Suspension-feeding · Cold ocean

\section{INTRODUCTION}

Sessile suspension-feeding organisms can experience short-term and long-term changes in environmental conditions (e.g. temperature, salinity and suspended particulate matter or seston). One of the most important environmental factors is the seston, which includes living plankton, organic detritus and inorganic particles.

\footnotetext{
- Present address: Instituto de Biología Marina, Universidad Austral de Chile, Casilla 567, Valdivia, Chile

" Addressee for correspondence;

E-mail: thompson@kean.ucs.mun.ca
}

The quantity of suspended particulate matter (SPM) and its quality as food for filter-feeders varies both temporally and spatially in response to physical and biological factors (Armstrong 1958, Berg \& Newell 1986). Among the principal factors that can influence the quantity and quality of the SPM are biological production (Anderson 1970, Widdows et al. 1979), aperiodic storms (Ward 1981, Gordon 1983), wind-wave resuspension (Soniat et al. 1984, Berg \& Newell 1986) and tidal resuspension (Incze \& Roman 1983, Anderson \& Meyer 1986, Fegley et al. 1992). A knowledge of the variation in the quality as well as the quantity of the natural diet available for suspension-feeding organisms 
is a significant component of any study of feeding behaviour. The importance of measuring temporal variability in seston quantity and quality is evident from some previous studies. For example, MacDonald \& Thompson (1985a, b) and Thompson \& MacDonald (1990) have shown a direct relationship between the food supply (seston) and tissue growth, reproductive output and synthesis of biochemical energy reserves in the suspension-feeder Placopecten magellanicus, and Bock \& Miller (1994) have demonstrated that the growth of the hard clam Mercenaria mercenaria responds to short-term changes in seston composition. Fréchette \& Bourget $(1985 a$, b) have described a gradient in particulate organic matter (POM) in the benthic boundary layer above a bed of mussels Mytilus edulis and have suggested that mussel growth is food-limited.

Many studies have been carried out on the seston of marine environments, but the majority have been concerned with quantifying either the POM or the concentration and size of the particles. According to Bayne et al. (1987), at least 3 features of dietary quality should be considered: (1) the size of the suspended particles; (2) the balance in the diet between biologically inert and metabolisable fractions; and (3) the biochemical composition of this metabolisable fraction. Nevertheless, only a few authors (Mayzaud \& Taguchi 1979, Widdows et al. 1979, Kranck 1980, Mayzaud et al. 1984, 1989, Poulet et al. 1986, Navarro et al. 1993) have considered the biochemical composition of the SPM, despite its potential value as an indicator of the nutritional value of the seston (Myklestad \& Haug 1972). Healey (1973) suggested that the ratio of protein to carbohydrate may be used as an indicator of nutrient deficiency for both cultured and natural populations of algae. Zeitzschel (1970) assumed that values of 100 or less for the ratio carbon: chlorophyll a (C:chl a) indicate that the carbon originates mainly from living phytoplankton, suggesting a rich food supply. According to Russell-Hunter (1970), the nutritional requirements of marine animals for proteins are satisfied by a food source with a $C: N$ ratio lower than 17 . The nutritive value of the SPM has also been related to the protein to carbohydrate to lipid ratio; Parsons et al. (1961) and Scott (1980) reported that for phytoplankton cultures, the required ratios are 4:3:1 or 1:1:1 in order to meet the food requirements of filter-feeders.

The natural diets of suspension-feeding organisms can fluctuate in time and space, consisting of assemblages of mixed particles having different nutritive values, depending on their biochemical composition (Conover 1978, Mayzaud et al. 1984, Poulet et al. 1986). According to Myklestad \& Haug (1972), the biochemical composition of the seston is a useful indicator of the nutritional value of the diet for suspensionfeeders. Factors such as the quality and quantity of particulate material in suspension are known to alter the physiological responses of bivalves to seasonal environmental changes (Worrall et al. 1983). The organisms must be able to respond efficiently to these changes to make maximum use of the available food.

The major objective of the present study was to characterise the SPM (seston) quantitatively and in detail in order to determine the seasonal changes in the nutritional value of the diet available to filterfeeding organisms, particularly the horse mussel Modiolus modiolus, which is common subtidally on rock surfaces in exposed locations such as Logy Bay, Newfoundland, Canada. A complementary study on the physiological ecology of this species was carried out at the same time (Navarro \& Thompson unpubl.). A sound knowledge of the nature of the food supply is essential for an understanding of the physiological responses of the suspension-feeder. A further objective was to compare the seston in a cold-ocean, coastal environment at mid latitudes with that of other marine environments which have been studied, mainly estuaries and bays in temperate regions.

\section{MATERIALS AND METHODS}

Study site. Logy Bay is located in southeast Newfoundland $\left(47^{\circ} 38^{\prime} \mathrm{N}, 52^{\circ} 40^{\prime} \mathrm{W}\right)$ and is typical of the exposed shorelines in this region in having precipitous cliffs, access to the sea being limited to coves and a few beaches composed of pebbles or large rocks, with a few areas of coarse sand. The ocean water is clear, with good visibility to a depth of about 20 to $25 \mathrm{~m}$, except during the spring runoff and phytoplankton bloom.

Collection of water samples. Water samples were obtained from August 1986 to August 1988 on a monthly, weekly or daily basis, depending on the time of year. Unfiltered seawater was pumped into clean buckets from the main seawater supply to the Ocean Sciences Centre at Logy Bay. The intake lies at $6 \mathrm{~m}$ depth, close to the rock face on which the horse mussels grow. The water was screened through a $275 \mu \mathrm{m}$ nitex mesh to eliminate large zooplankton and debris before analysis of the major components of the seston. Diatom chains were not retained by this screen. For total (TPM), organic (POM) and inorganic (PIM) particulate matter, chl $a$ and phaeopigments, particulate organic carbon (POC) and nitrogen (PON), and particulate carbohydrate and lipid, known volumes of water ( 3 to 4 l) were immediately filtered under gentle vacuum through washed, precombusted, preweighed Whatman GF/C filters of diameter $4.7 \mathrm{~cm}$ (except 0.51 water and $2.5 \mathrm{~cm}$ filter for pigment analysis). Filters were stored in darkness at $-20^{\circ} \mathrm{C}$ until the analyses were done. Blank filters for all the seston analyses 
were prepared on each collection date and treated in the same manner as the samples, and corrections made for values from these blanks. Determinations of particle numbers and of the size-frequency distributions of particles were made immediately after collection of water samples. At each sampling time, water temperature was recorded to the nearest $0.1^{\circ} \mathrm{C}$

Suspended particulate matter (seston). Filters with retained SPM were rinsed with $10 \mathrm{ml}$ isotonic ammonium formate to remove salt and prevent cell lysing. The filters were dried at $80^{\circ} \mathrm{C}$ for $24 \mathrm{~h}$, weighed, combusted at $450^{\circ} \mathrm{C}$ for $3 \mathrm{~h}$ and reweighed after cooling in a desiccator. POM was obtained by difference. A Cahn microbalance was used throughout.

Chl $a$ and phaeopigments. The fluorometric technique described by Yentsch \& Menzel (1963) was followed, as modified by Parsons et al. (1984). The pigments were extracted from the filters with $90 \%$ acetone for $20 \mathrm{~h}$ at $5^{\circ} \mathrm{C}$ in darkness. Samples were then centrifuged to remove glass fibres, and chloropigments determined in the supernatant with a Turner Designs Fluorometer (Model 10). Pure chl a (Sigma, St. Louis, MO, USA) was used as a calibration standard.

POC and PON. Organic carbon and nitrogen were determined using a Perkin-Elmer CHN Elemental Analyser (Model 240 A) with acetanilide as a standard.

Particle size distribution. The size-frequency distribution of particles above $2.0 \mu \mathrm{m}$ equivalent spherical diameter was analysed with a Coulter Counter Model TAII. According to Bayne et al. (1977), many filterfeeding bivalves are able to retain particles above $2.0 \mu \mathrm{m}$ with $100 \%$ efficiency. Since the Coulter Counter can detect particles between 2 and $40 \%$ of the orifice diameter of the tube, $100 \mu \mathrm{m}$ and $280 \mu \mathrm{m}$ orifice tubes were most appropriate and were used in the present study. Eighteen size categories representing diameters from 2 to $102 \mu \mathrm{m}$ were measured, and size distributions were expressed as volume versus log particle size (Sheldon \& Parsons 1967). Latex spheres (9.8 $\mu \mathrm{m}$ diameter) and ragweed pollen (19 to $20 \mu \mathrm{m}$ diameter) were used to calibrate the $100 \mu \mathrm{m}$ and $280 \mu \mathrm{m}$ tubes respectively. No coincidence corrections were necessary, since counts in all channels were always below the $5 \%$ coincidence level.

Microscopic analysis. Screened water samples $(100 \mathrm{ml})$ were fixed in Lugol's iodine and stored at $4^{\circ} \mathrm{C}$. The contents were allowed to settle and concentrated onto a microscope slide for examination with a Zeiss Axiovert 35 inverted microscope (Utermöhl 1958).

Particulate carbohydrate. SPM was concentrated by filtering 3 to $4 \mathrm{l}$ of seawater through a precombusted $\mathrm{GF} / \mathrm{C}$ filter $(4.7 \mathrm{~cm}$ diameter) for the determination of carbohydrate by the phenol-sulphuric acid method of Dubois et al. (1956), after extraction in hot $5 \%$ trichloroacetic acid (TCA) containing $0.1 \%$ silver sul- phate (Barnes \& Heath 1966). Samples and filter blanks were cut into small pieces and homogenised for $1 \mathrm{~min}$ in $4 \mathrm{ml} 5 \%$ TCA with a Polytron homogeniser. The homogenate was boiled for $30 \mathrm{~min}$ to hydrolyse the complex sugars and centrifuged $(20 \mathrm{~min}$ at $3000 \times g)$. The precipitate was washed with $2 \mathrm{ml}$ distilled water and the sample recentrifuged. The supernatant and washings were made up to $10 \mathrm{ml}$ with distilled water The concentration of carbohydrate in the supernatant was estimated in triplicate using a glucose standard.

Particulate lipid. Particulate lipid was determined by filtering a known volume of water (3 to 4 l) through a precombusted GF/C filter $(4.7 \mathrm{~cm}$ diameter $)$. The samples and filter blanks were cut into small pieces and homogenised for $1 \mathrm{~min}$ in $2 \mathrm{ml}$ chloroform: methanol $(2: 1 \mathrm{v} / \mathrm{v})$ with a Polytron homogeniser. After centrifugation ( 10 min at $1000 \times g$ ) the supernatant was removed and heated at $50^{\circ} \mathrm{C}$ for $5 \mathrm{~h}$ to evaporate the solvents. The lipid residue was then charred at $200^{\circ} \mathrm{C}$ after the addition of $0.5 \mathrm{ml}$ concentrated sulphuric acid. Lipid was estimated spectrophotometrically by the method of Marsh \& Weinstein (1966), with tripalmitin as a standard.

Particulate protein. Particulate protein was determined by multiplying the PON values by 5.8 (Gnaiger \& Bitterlich 1984). Although this factor was originally established for living tissue, we believe that it is probably a reasonable approximation for seston in Logy Bay.

Food index. An evaluation of the nutritional value of the seston to the horse mussel throughout the year was made using the values for the biochemical composition. Thus food quantity was defined as the sum of the concentrations of protein, carbohydrate and lipid, and a food index was calculated [(Food/Total Seston $) \times 100]$ as the percentage of food in the seston (Widdows et al. 1979). Protein, carbohydrate and lipid were converted into energy equivalents using the coefficients 24.0, 17.5 and $39.5 \mathrm{~J} \mathrm{mg}^{-1}$ respectively (Gnaiger 1983).

Statistical analysis. Environmental data were analysed by Pearson product-moment correlation following $\log _{10}$ or arcsine transformation of the variables to reduce the dependence of the sample variance on the mean and to normalise the distribution of the data. SYSTAT version 4.0 for the microcomputer was used (Wilkinson 1988).

\section{RESULTS}

\section{Temperature and suspended particulate matter}

Temperature increased from a minimum value of ca $-1.0^{\circ} \mathrm{C}$ during February-March to a maximum of ca $14.0^{\circ} \mathrm{C}$ in August (Fig. 1A). This maximum value was not maintained for very long, decreasing throughout late summer and early winter. 
Fig. 1. (A) Seasonal temperature cycle. (B) Monthly means for total particulate matter (TPM) and particulate organic matter (POM). When no SE bars are shown, they are smaller than the symbols

Maximum values for TPM were observed in April-May and lower values during the rest of the year (Fig. 1B). The peak observed in January 1988 corresponds to a severe winter storm which occurred before and during the sampling (January 27), and the rough sea conditions were reflected mainly in the inorganic component of the seston (PIM). On a monthly basis (Fig. 1B) POM was fairly constant, but individual values as low as $0.19 \mathrm{mg} \mathrm{l}^{-1}$ (April 10,1987 ) and as high as $2.13 \mathrm{mg} \mathrm{l}^{-1}$ (May 19, 1987 - bloom) were recorded. Maximum values for TPM were also obtained during the phytoplankton bloom (ca $3.0 \mathrm{mg} \mathrm{l}^{-1}$ ). The fluctuations in TPM in Logy Bay were attributable
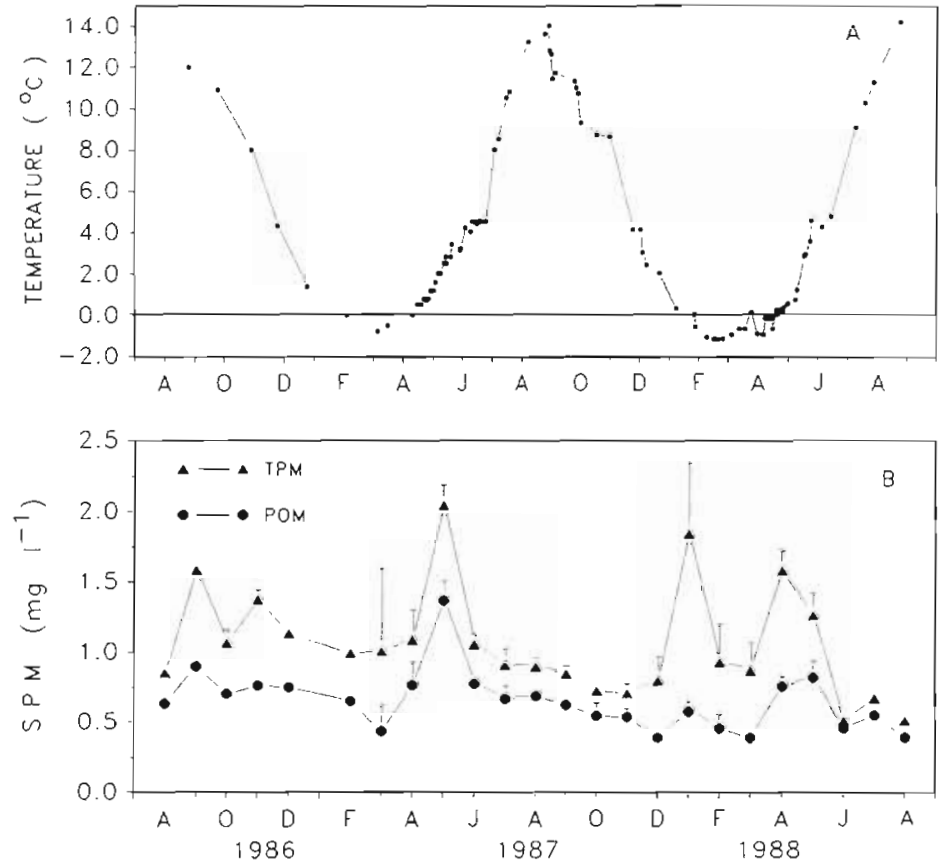
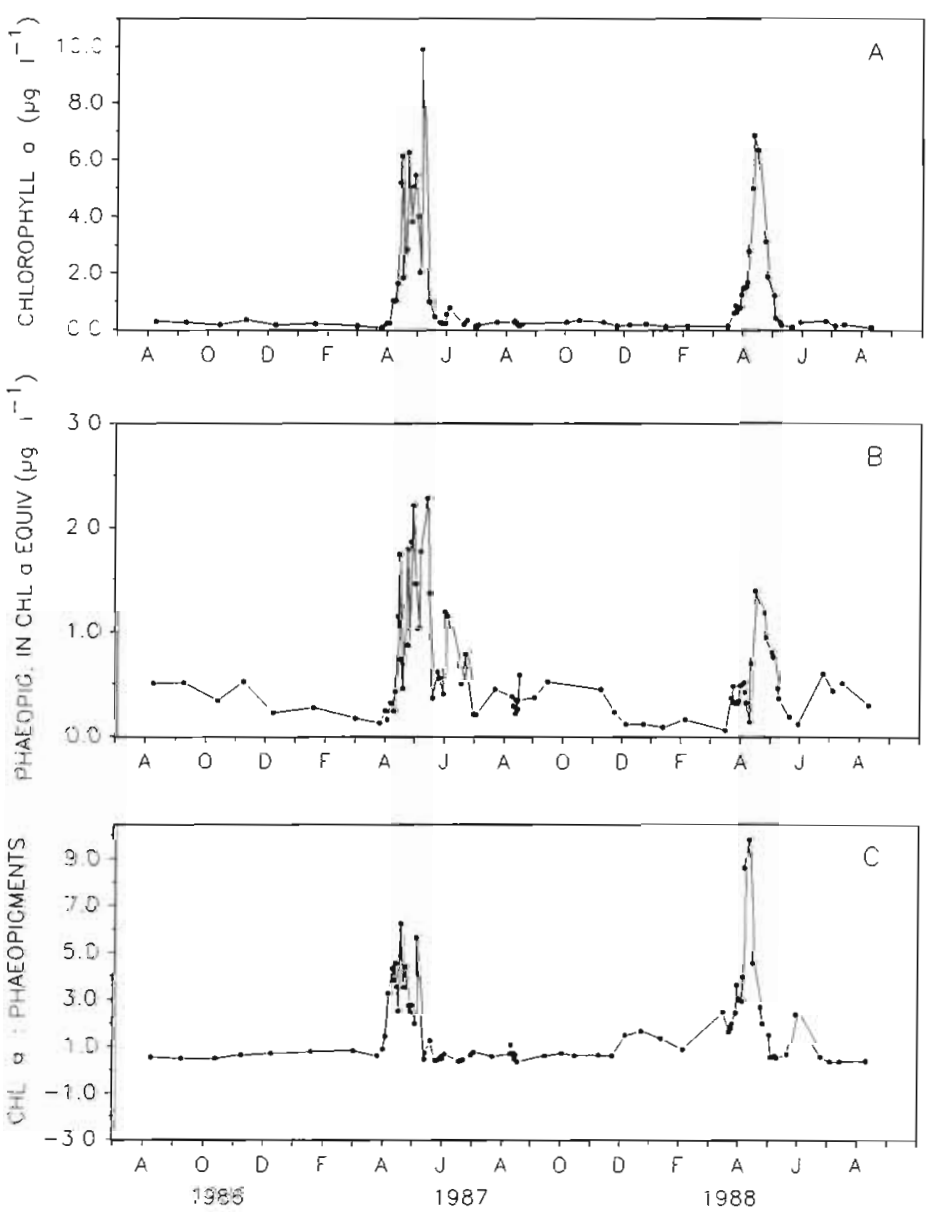

Fig. 2. Seasonal cycles of (A) chl a, (B) phaeopigments as chl a equivalents, and $(C)$ chl a:phaeopigment ratio largely to the POM and only in exceptional cases were they caused by changes in the PIM component.

\section{Chlorophyll $a$ and phaeopigments}

The concentration of chl a exhibited a marked spring peak (April-May), then declined abruptly during late spring to show a minimum in fall and winter (Fig. 2A). In 1987 the peak was higher $\left(9.9 \mu \mathrm{g} \mathrm{l}^{-1}\right)$ than in $1988\left(6.9 \mu \mathrm{g} \mathrm{l}^{-1}\right)$, although the duration of both peaks was very similar ( 4 to 5 wk). During the rest of the year (July-March) the chl a concentration was very low, with values around $0.25 \mu \mathrm{g} \mathrm{l}^{-1}$. No fall bloom was observed in either year, suggesting that the main input of energy in the form of phytoplankton occurs during a very short period of the year

Phaeopigments (expressed in chl a equivalents) fluctuated in a similar fashion to chl $a$, with lower values in 1988 than in 1987 (Fig. 2B). Higher values (ca $2.0 \mu \mathrm{g} \mathrm{l}^{-1}$ ) were recorded during the spring bloom, but a second peak (ca $1.0 \mu \mathrm{g} \mathrm{l}^{-1}$ ) appeared in June of each year. Phaeopigment concentrations were very low $\left(\leq 0.3 \mu \mathrm{g} \mathrm{l}^{-1}\right)$ during winter. For most of the year the concentration of phaeopigments was higher than that of chl $a$, with a chl a: phaeopigment ratio of 0.40 to 0.80 (Fig. $2 \mathrm{C}$ ), although during the phytoplankton bloom this ratio reached values as great as $6.2(1987)$ and 9.8 (1988). 


\section{POC and PON}

The seasonal cycles for POC and PON resembled those of $\mathrm{chl}$ a and POM, the highest concentrations usually occurring during the spring phytoplankton bloom (Fig. 3A, B). Thus POC was a maximum in April-May of 1987 and 1988, with values near 800 and $450 \mathrm{\mu g}^{-1}$ respectively. The isolated high value for August $1987\left(476 \mu \mathrm{g} \mathrm{l}^{-1}\right)$ was not associated with a high chl a concentration (Fig. 2A). POC levels gradually decreased after the spring peaks, with fall values ranging between $130 \mu \mathrm{g} \mathrm{l}^{-1}$ in 1987 and $160 \mu \mathrm{g} \mathrm{l}^{-1}$ in 1988. The lowest POC values were recorded during the 2 winter periods, with concentrations as low as ca $50 \mathrm{\mu g} \mathrm{l}^{-1}$ in 1987 and ca $70 \mu \mathrm{g} \mathrm{I}^{-1}$ in 1988.

The seasonal pattern of PON (Fig. 3B) was very similar to that of $\mathrm{POC}$, with major peaks during the phytoplankton bloom of $1987\left(125 \mu \mathrm{g} \mathrm{l}^{-1}\right)$ and $1988\left(85 \mu \mathrm{g} \mathrm{l}^{-1}\right)$. As with POC, there were some high PON values during summer which were not associated with high chl a values. A second peak of PON was observed in June 1987. immediately after the spring bloom. PON continued to decrease throughout fall and winter, with values as low as $12.0 \mathrm{\mu g} \mathrm{l}^{-1}$ in winter 1987 and $20 \mathrm{\mu g} \mathrm{l}^{-1}$ in winter 1988.

The C:chl a ratio estimates the relative detrital content of the seston (Zeitzschel 1970), and values of 100 or less are considered to indicate that the carbon originates primarily from living phytoplankton. C:chl a ratios were lowest $(<100)$ during the phytoplankton bloom in both years (Fig. $3 \mathrm{C}$ ), but exceeded 100 at all other times, the greatest values occurring during the summer of 1987.

The C:N ratio did not show a clear seasonal pattern, and values varied from 2.5 (June 15, 1987) to as high as 12.2 (August 23, 1987), with a mean of 5.5 for the entire study period (Fig. 3D).

\section{Particle size distribution}

The quantity of particles in suspension was strongly influenced by the spring bloom and by resuspension during storms. The main peaks in particle numbers and in total volume occurred during the spring bloom of each year of the study, although the peak for particle volume was less marked in 1988 than in 1987 (Fig. 4). The peaks observed in January 1988 for both variables coincided with a continued period of rough sea condi-
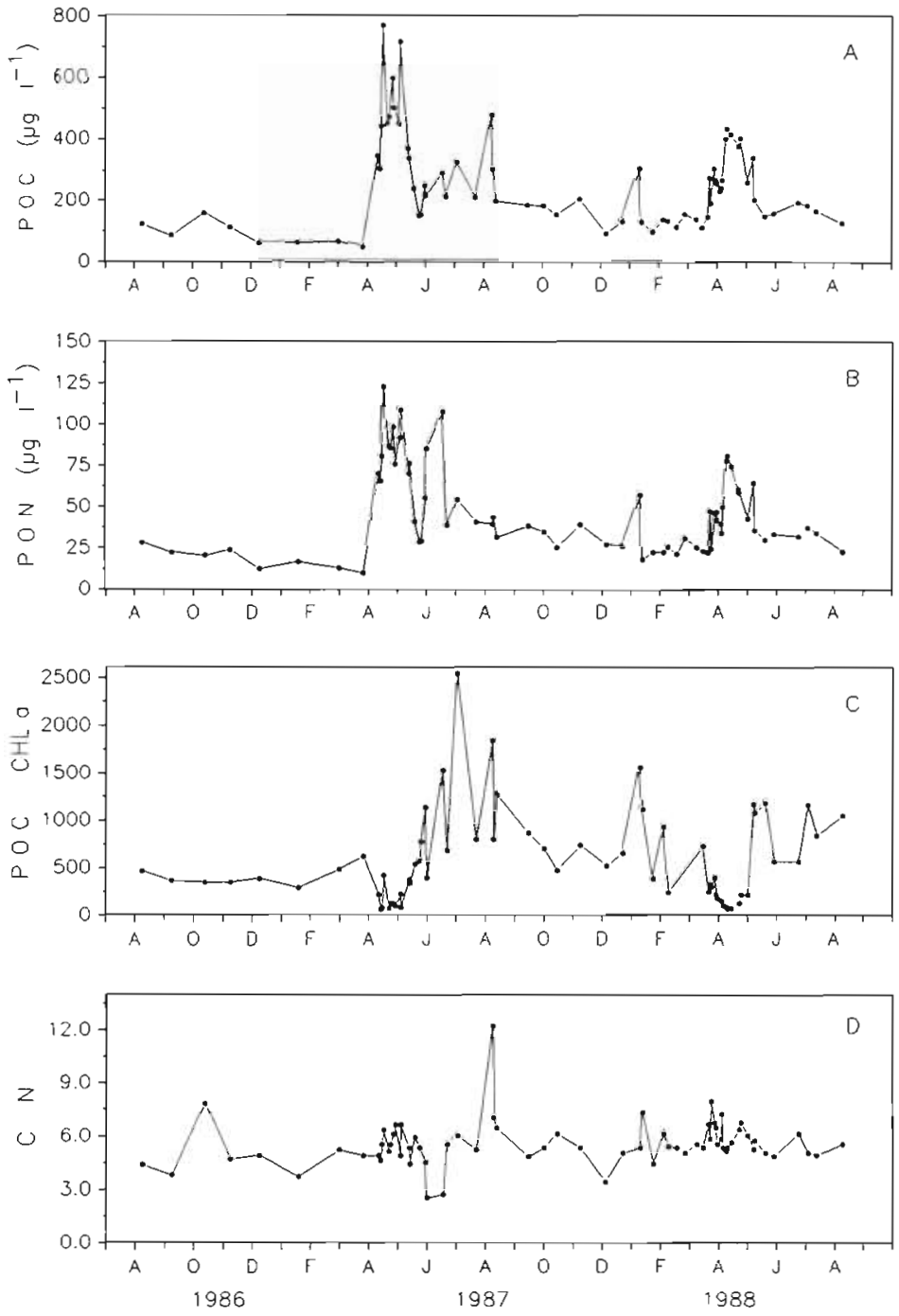

Fig. 3. Seasonal variation in (A) particulate organic carbon (POC), (B) particulate organic nitrogen (PON), (C) POC: chl a ratio, and (D) C:N ratio

tions in Logy Bay, but these values never exceeded those recorded during the phytoplankton bloom. There were also peaks in particle volume during October 1987 and July 1988 that were not associated with increases in particle numbers. The spring peaks of particle numbers and volume (Fig. 4A, B) were associated mainly with single and chain-forming diatoms, such as Fragilaria sp., Thalassiosira sp., Coscinodiscus sp., and Chaetoceros sp. Autotrophic flagellates were more abundant during the last part of the phytoplankton bloom (May-June), with diameters from 6 to $12 \mu \mathrm{m}$.

Before the phytoplankton bloom occurred (March 1987) the particle size distribution profile was very flat (Fig. 5), followed in April by a small peak in the range 10 to $30 \mu \mathrm{m}$ diameter, increasing considerably during May with a peak at 20 to $60 \mu$ diameter. Samples taken simultaneously for microscopic analysis showed 
that the predominant particles during the phytoplankton bloom were single as well as chain-forming diatoms (Fragilaria sp., Nitzschia sp., Chaetoceros sp., Thalassiosira sp., and Coscinodiscus sp.) in the upper part of the size range, with flagellates in the lower part of the size range. June 1987 was characterised by a marked decrease in the peak, representing the spring bloom crash and suggesting a reduced number of diatoms. This condition continued throughout July, August and September, although in July and August a peak was also observed at $5 \mu \mathrm{m}$ diameter, probably attributable to an increase in the microflagellate population. The peak recorded in October (Fig. 5) corresponded to large detrital particles (50 to $100 \mu \mathrm{m}$ ), a situation that was also observed during the following winter months (December-February).

The size spectrum for May 1988 was similar to that of the year before, although the diatom peak was smaller in 1988 than in 1987 (Fig. 5). June 1988 showed 2 peaks, the first in the range 4 to $5 \mu \mathrm{m}$, probably representing a population of flagellates, as was observed in 1987 and the second in the range 30 to $40 \mu \mathrm{m}$. The latter was much smaller than it had been in the previous $2 \mathrm{mo}$, reflecting the crash of the diatom bloom (Fig. 5).

\section{Biochemical composition of the seston}

The carbohydrate concentration showed a very similar seasonal pattern in both years of the study (Fig. 6A), ranging from 4.8 to $118 \mu \mathrm{lg}^{-1}$ during 1987 and from 6.4 to $124 \mathrm{\mu g} \mathrm{l}^{-1}$ in 1988 . The mean for the entire sampling period was $30.6 \mu \mathrm{gl}^{-1}$, and peak values were recorded during the phytoplankton bloom of each sampling
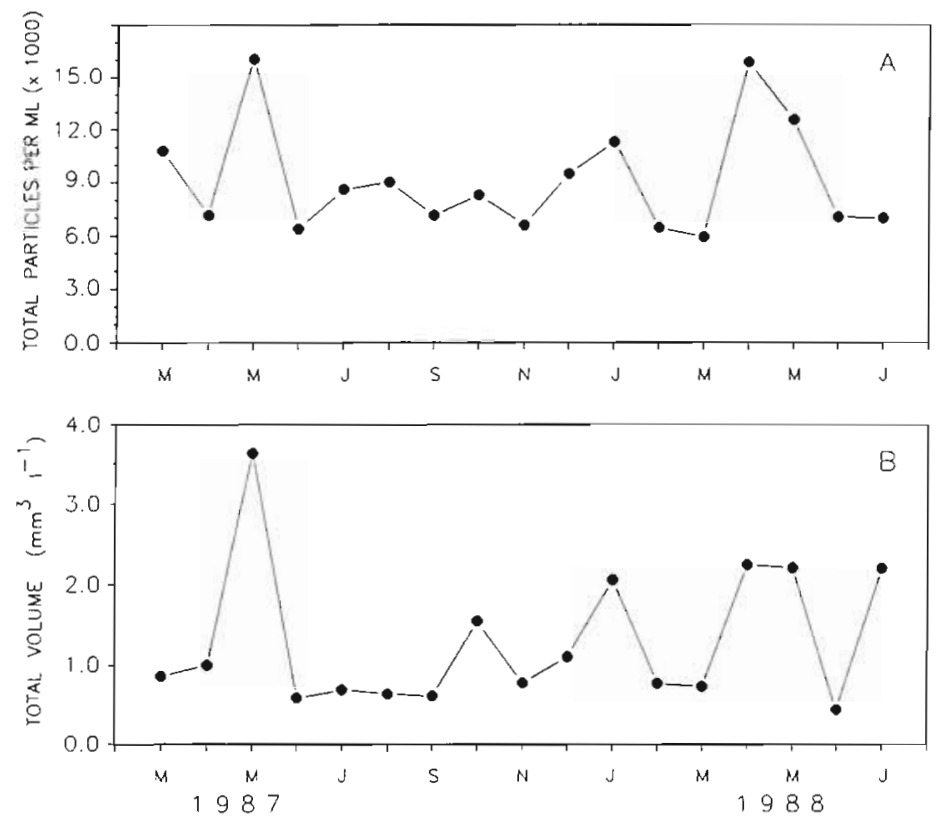

year (April-May), with smaller peaks occurring during summer (June-July).

The seasonal variation in particulate lipid (Fig. 6B) was similar to the cycles shown by other components of the seston (e.g. chl a, carbohydrate, PON, POC). Lipid concentration ranged between 16.3 and $74.0 \mu \mathrm{g} \mathrm{I}^{-1}$ in the first year of the study and between 15.3 and $77.7 \mu \mathrm{g}$ $\mathrm{l}^{-2}$ in the second year. The lipid content of the seston was lower during fall and winter, increasing significantly during the 4 to $5 \mathrm{wk}$ of the phytoplankton bloom. The mean concentration over 2 yr of sampling was $35.3 \mu \mathrm{g} \mathrm{l}^{-1}$.

Maximum protein levels were observed during April-May in both years of the study (Fig. 6C), but the peak was greater in 1987 ( $712 \mu \mathrm{g} \mathrm{l}^{-1}$ ) than in $1988\left(467 \mathrm{\mu g} \mathrm{l}^{-1}\right.$ ). During the rest of the year values around $200 \mu \mathrm{g} \mathrm{l}^{-1}$ were recorded. The smaller peak in protein observed in January 1988 coincided with an increase in TPM (Fig. 1B), attributable to rough sea conditions produced by a winter storm. At certain periods of the year, such as during the phytoplankton bloom, particulate protein accounted for more than $70 \%$ of the organic seston (e.g. May 1, 1987). In contrast, very low values were found during some winter months (e.g. February 1987, January 1988), when protein constituted about $10 \%$ of the mass of organic seston.

The energy content of the seston was lowest during the winter (December-March) in each year, increasing during the spring bloom to reach maximum values in May (Fig. 6D). The peak value was greater in 1987 than in 1988.

\section{Food index}

Of special interest here are the relationships among the various organic components of the SPM that may be utilised by suspension-feeders as a nutritional source. The food material (FM) present in the total seston (Fig. 7) is represented by the sum of carbohydrate, lipid and protein concentrations (Widdows et al. 1979, Soniat et al. 1984). The FM reached a maximum during the phytoplankton bloom of each year, with values of $671 \mathrm{\mu g} \mathrm{l}^{-1}$ in 1987 and $630 \mathrm{\mu g} \mathrm{l}^{\mathrm{l}}$ in 1988. The lowest values occurred during the winters of 1987 and 1988, with concentrations of 100 and $120 \mathrm{\mu g} \mathrm{l}^{-1}$ respectively (Fig. 7A).

Fig. 4. Seasonal variation in the size-frequency distribution of the SPM, expressed as (A) total particles $\mathrm{mI}^{-1}$ and (B) total volume 

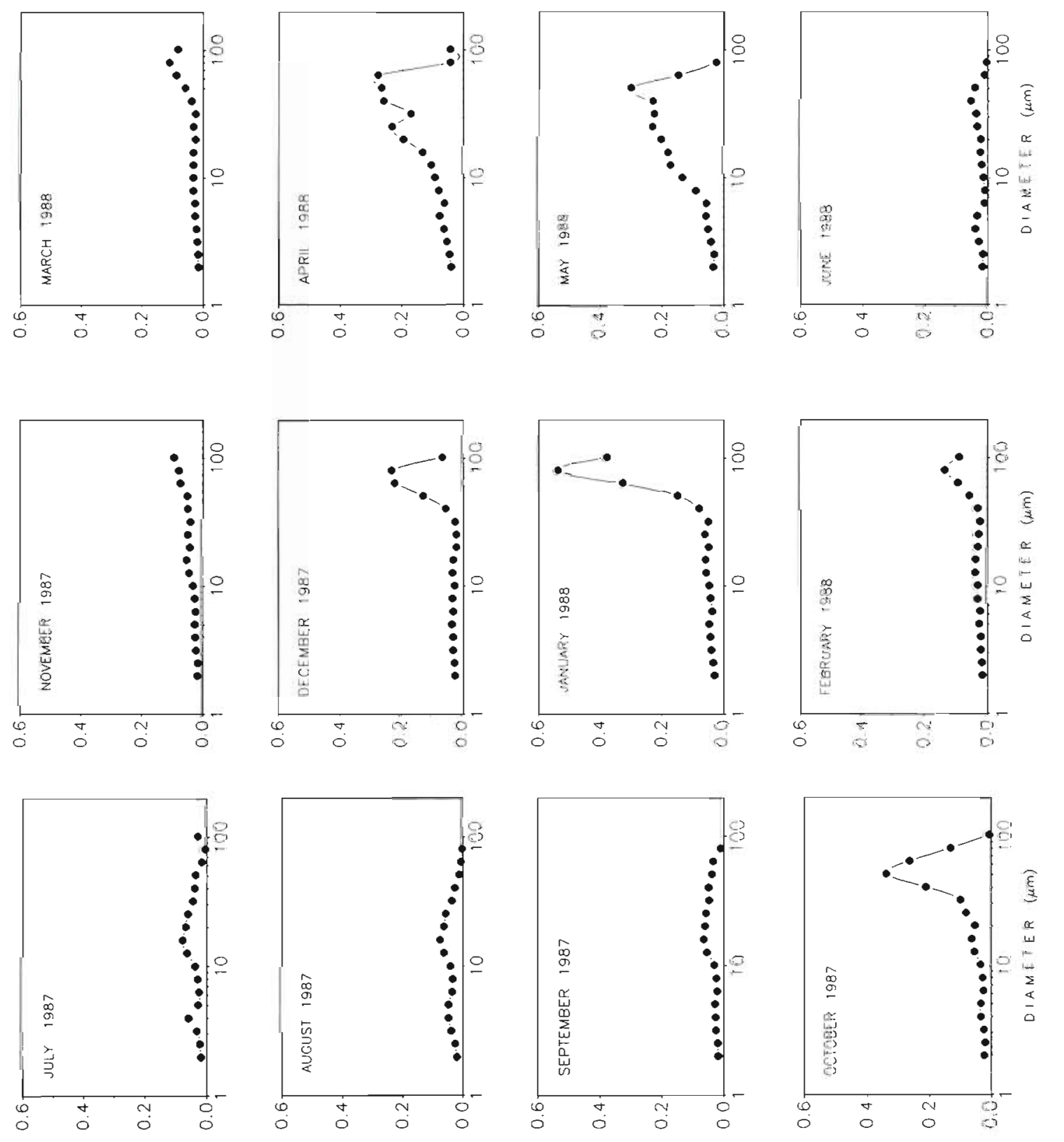

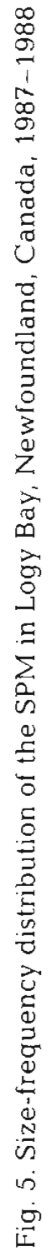
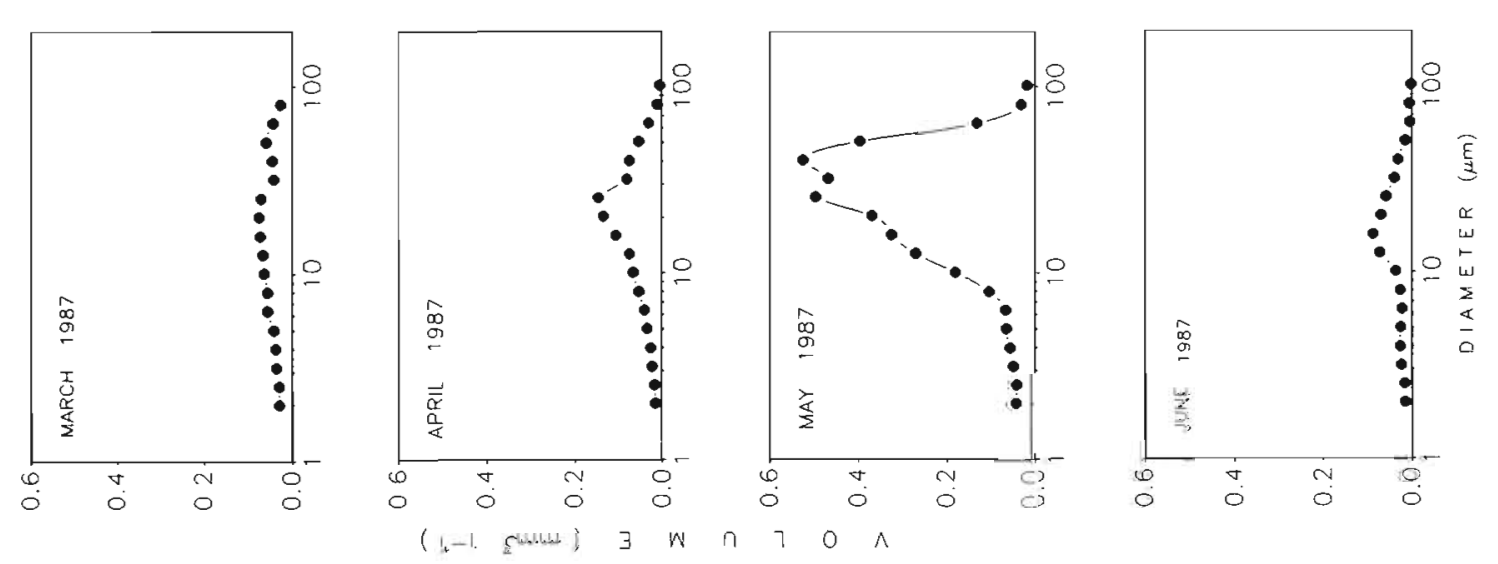
The FM (carbohydrate + lipid + protein) expressed as a percentage of the SPM (by weight) represents an index of the quality of the food available to suspension-feeders such as the horse mussel (Fig. 7B). Peak values for the food index coincided with the spring bloom (53.6\% in April 1987 and $42.1 \%$ in April 1988). In winter, the food index dropped to a small percentage of the total seston (ca 8\% in 1987 and ca $7 \%$ in 1988), because the seston was then composed mainly of inorganic matter (ca $66 \%$ ), representing a low-quality diet for the suspension-feeding organisms.

\section{DISCUSSION}

Shallow marine coastal systems in cold waters have a higher biomass and a larger diversity of particles than oceanic systems, much of this diversity being associated with seasonal pulses of different classes of phytoplankton and microplankton (Mayzaud \& Taguchi 1979, Malone 1981). The suspended particulate load (seston) in Logy Bay is lower than in many shallow marine bays, owing partly to a relatively small terrigenous input to Logy Bay and partly to the absence of silt, and the quantity of POM primarily depends upon phytoplankton productivity. Since phytoplankton is considered to be superior to other POM as food for filter-feeders (Jørgensen 1975), the period April-June is probably the most important for the nutrition of filter-feeding organisms in this environment.

Seston concentrations are lower in Logy Bay than in many other environments inhabited by suspension-feeding bivalves. Widdows et al. (1979) reported values for total seston in the Lynher estuary (southwest England) in the range 4 to $35 \mathrm{mg} \mathrm{l}^{-1}$, similar to data obtained in southern Chile by Navarro et al. (1993). Large amounts of TPM (up to $152 \mathrm{mg} \mathrm{l}^{-1}$ ) were reported by Griffiths (1980) for Bailey's Cottage, South Africa, although much of it was sand and the POM fraction was considerably lower. At Tromsø, Norway, Vahl (1980) recorded values similar to ours, with POM in the range 1 to $4 \mathrm{mg} \mathrm{l}^{-1}$, although TPM was considerably higher ( 5 to $12 \mathrm{mg} \mathrm{l}^{-1}$ ) than in Logy Bay. Newell \& Bayne (1980) described a more complex seasonal pattern of seston for the Tamar estuary, southwest England, with an annual range in TPM of $3 \mathrm{mg} \mathrm{l}^{-1}$ in summer to $28 \mathrm{mg} \mathrm{I}^{-1}$ during winter. Conversely, the
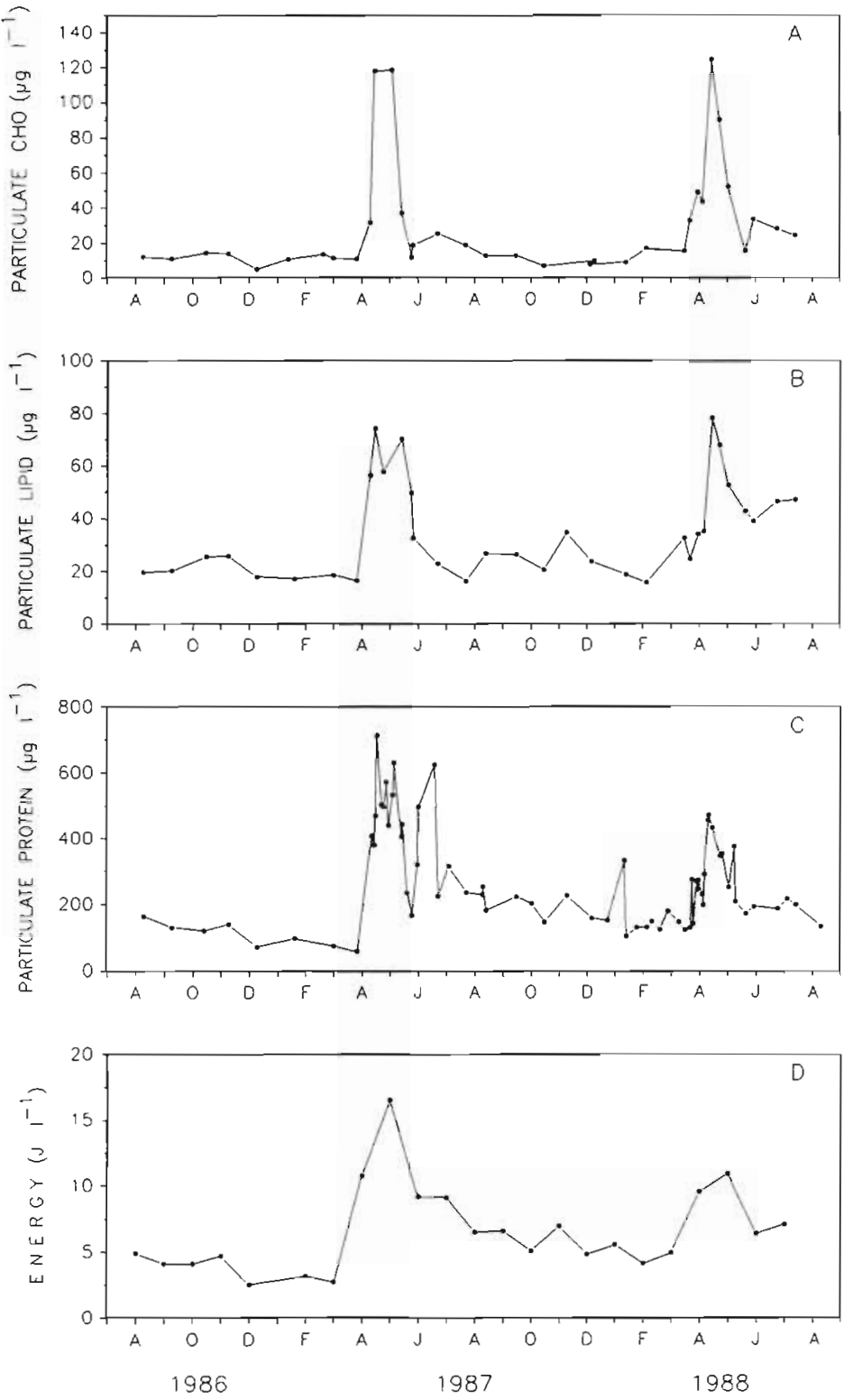

Fig. 6. Seasonal cycle in (A) carbohydrate, (B) lipid, (C) protein, and (D) energy content of the SPM

POM component in the Tamar is at a minimum during winter $\left(1.5 \mathrm{mg} \mathrm{l}^{-1}\right)$ and at a maximum in summer (3.0 $\mathrm{mg} \mathrm{l}^{-1}$ ), which is slightly higher than our values for Logy Bay. Thompson (1984) described the monthly fluctuations of TPM and POM for Bellevue, Trinity Bay, Newfoundland, with very similar values to ours. POM varies from 1 to $3 \mathrm{mg} \mathrm{l}^{-1}$ at Bellevue, whereas at Logy Bay it varies from 0.25 to $2.0 \mathrm{mg} \mathrm{l}^{-1}$ (Fig. 1B). TPM is greater at Bellevue ( 2 to $6 \mathrm{mg} \mathrm{l}^{-1}$ ) than at Logy Bay $\left(0.3\right.$ to $\left.3.0 \mathrm{mg} \mathrm{1}^{-1}\right)$. More recently, Berg \& Newell (1986) described the fluctuations in seston over $18 \mathrm{mo}$ in 2 inlets of Chesapeake Bay, USA, in which TPM varied between 3.5 and $30 \mathrm{mg} \mathrm{I}^{-1}$ and POM between 

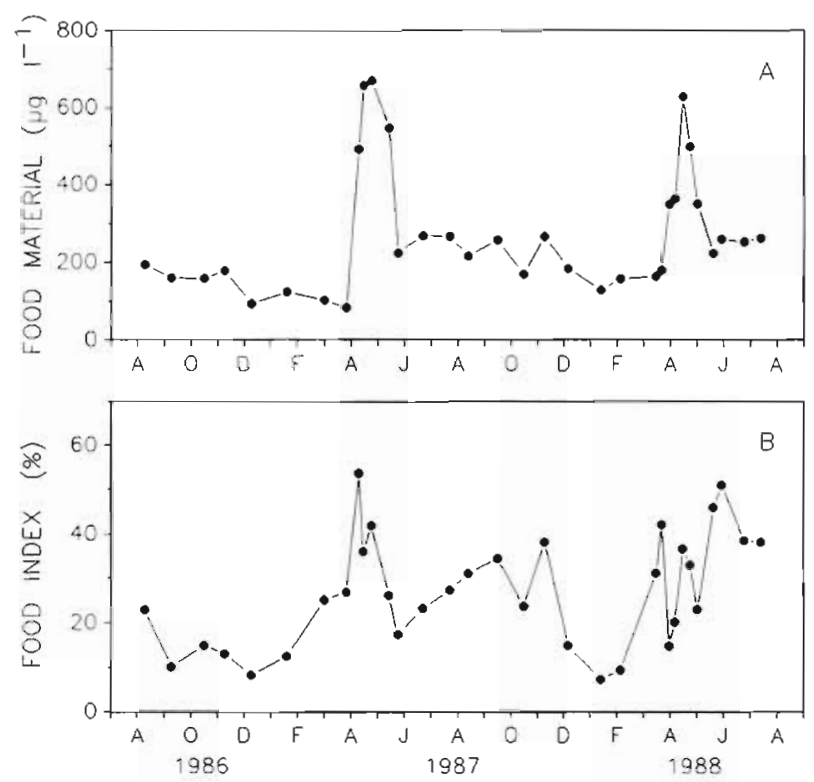

Fig. 7. Seasonal fluctuation in (A) the concentration of food material and $(B)$ the food index

1.5 and $8 \mathrm{mg} \mathrm{l}^{-1}$. In most cases PIM is the component of the seston that shows the greatest seasonal fluctuations, and POM is normally greatest during the late spring or summer.

The spring phytoplankton bloom in Logy Bay typically shows 1 annual peak when the concentration of chl $a$ in the water increases to 50 to 90 times the winter level (Fig. 2A). The seasonal pattern is similar to those found by other authors in the northern hemisphere (Cadée 1982, Mayzaud et al. 1984, MacDonald \& Thompson 1985a, Berg \& Newell 1986, Pomeroy \& Deibel 1986) and in the southern hemisphere (Navarro et al. 1993). The phytoplankton bloom is not suppressed by low temperature; it begins when the water temperature is still below $0^{\circ} \mathrm{C}$ (Figs. 1 \& $3 \mathrm{~A}$ ), confirming observations by MacDonald \& Thompson (1985a) and Pomeroy \& Deibel (1986). The absence of a fall bloom in Logy Bay is consistent with observations for other mid latitude environments, such as in northern Europe (Cadée 1982, Christensen \& Kanneworff 1985) and eastern Canada (Kranck 1980, Thompson 1984), suggesting that energy input to benthic filter-feeders in the form of phytoplankton is concentrated into a short period of the year in these cool, temperate regions. Dead plant material, measured as phaeopigments and expressed in chl a equivalents, shows a main peak in Logy Bay coincident with that observed for chl $a$, but a second peak also occurs during July of each year (Fig. 2B), which is probably attributable to grazing on the decaying phytoplankton bloom by pelagic herbivores.
The differences in composition of the POM at various times of the year are evident from the ratio of chl a to phaeopigments (Fig. 2C). This ratio largely exceeds unity during the phytoplankton bloom, compared with lower values associated with the more degraded material present during the rest of the year. Similar results were obtained for the Bedford Basin, Canada, by Mayzaud \& Taguchi (1979). Wassmann \& Aadnesen (1984), working in a shallow fjord system on the west coast of Norway, reported high values of the chl a: phaeopigment ratio during mid-April, when the phytoplankton bloom was at its maximum. Christensen \& Kanneworff (1985) measured the chl a:phaeopigment ratio in 4 species of filter-feeding organisms from the North Sea, and found that it strongly reflected the proportion of living phytoplankton in the water.

POC and PON show a marked seasonal variation which is mainly controlled by the seasonal productivity cycle in Logy Bay (Fig. 4A, B). Similar variations at this latitude have been reported by Cadée (1982), Mayzaud et al. (1984) and Pocklington (1985). Values in Logy Bay are about 4 times lower than in Yaldad Bay, southern Chile (Navarro et al. 1993). The isolated peaks of POC and PON occurring during summer 1987 were not associated with high chl a values, suggesting the presence of microheterotrophs and/or kelp detritus in the water The unexpectedly high values for POC and PON in winter (January 1988) correspond with TPM but not with chl a. This discrepancy is explained by the rough sea conditions observed at this time, which may have caused fragmentation of kelp and/or importation of resuspended material. The food quality of the seston during these peaks is lower than it is when the seston is mainly composed of phytoplankton. Thus our values for the $C$ : chl a ratio exceed 100 for most of the year (Fig. 3C), suggesting a low concentration of microalgae in the water, but during April-May of both years the carbon present in the seston was primarily of phytoplanktonic origin, because the C:chl a ratio was usually below 100 . Similar trends were observed by Berg \& Newell (1986) on the eastern side of Chesapeake Bay.

According to Pocklington \& Leonard (1979) a value greater than 6.9 for marine POM implies a contribution from terrestrial sources or an 'ageing'. The $\mathrm{C}: \mathrm{N}$ ratio for seston in Logy Bay is below 6.9 for most of the year (Fig. 3D), but it is not clear that the material is always rich in phytoplankters. Thus the peak in the C:N ratio observed during August 1987 could be associated with zooplankton faeces, kelp detritus or the 'ageing' of the POM after the plankton blooms. Although our data set contains 2 C:N values (2.5 and 2.6) in June 1987 which are anomalous, because they lie below minima expected for planktonic organisms, including bacterioplankton, the mean value (by weight) is 5.5 , equivalent 
to 6.4 by atomic ratio, which is very close to the value 6.6 derived for phytoplankton from the Redfield ratio (Reichardt \& Dieckmann 1985). Our data also support those of Dawson et al. (1985), who reported a mean C:N value (by weight) of 6.1 for seston from the Antarctic.

Kranck (1980) distinguished 4 basic types of particle size distribution in the marine environment. We observed these in Logy Bay, although not all were present at any given time of the year. In March 1987, the size spectrum could be described as a type $\mathrm{D}$ or flat spectrum, characterised by low total concentrations with similar volumes of particles of all sizes, i.e. no pronounced peaks. This type of particle distribution is normally associated with living cells or detritus in low concentration. Kranck (1980) described the type D spectrum in terms of particles forming the background of the 'bloom spectrum' (type A). The type A or bloom spectrum recorded in Logy Bay during May 1987 (Fig. 5) was primarily a result of the phytoplankton bloom superimposed on a low background of about the same volume in all size classes (type D). Microscopic analysis of the samples showed that the peak is composed predominantly of single as well as chainforming diatoms (Fragilaria sp., Nitzschia sp., Chaetoceros sp., Thalassiosira sp. and Coscinodiscus sp.). Flagellates 8 to $12 \mu \mathrm{m}$ in diameter are also present. The particle size distribution for June-September 1987 corresponds to the type D or flat spectrum, whereas the peaks observed during winter months correspond to the type B or floc spectrum (Fig. 5), which contains very few plankton cells and is normally composed of suspended bottom sediment with a high proportion of inorganic matter.

The peaks registered in the particle size spectra during April and May 1988 (Fig. 5) were caused by the diatoms and flagellates of the phytoplankton bloom, as in 1987, but in 1988 particle concentrations did not attain the values of May 1987, as a result of weather conditions in Logy Bay. Spring 1988 was cloudy and stormy, and relatively low values were recorded for many of the nutritional components of the seston, such as chl a, PON, and POC. The bloom spectra observed in 1987 and 1988 coincided with the seasonal chl a maxima. Thus the particle size-frequency distributions obtained in the present study are very similar to those described by Kranck (1980) in Nova Scotia and by MacDonald \& Thompson (1985a) in Sunnyside, Newfoundland, where the size spectra can display types $A$, $B, C$ or $D$, depending on the biological and physical conditions prevailing at a given time of the year, particularly productivity cycles, kelp fragmentation, erosion, storms and resuspension.

For much of the year the trends in carbohydrate, lipid and protein are similar to that of chl $a$, with which all 3 variables are closely correlated $(r=0.88,0.71$ and
0.73 respectively, all significant at $p=0.01)$. This confirms that the nutritional character of the seston of Logy Bay is highly dependent on the phytoplankton bloom occurring during April-May every year. However, a secondary peak in protein was observed during late June 1987, suggesting the presence of microheterotrophs during the decaying bloom. Conversely, lower values for carbohydrate, lipid and protein occur during the rest of the year, when the concentration of the phytoplankters is low in this environment.

When all these biochemical components are combined, they account for 10 to $45 \%$ by weight of the POM during winter, which is considerably lower than during the phytoplankton bloom, when they represent 50 to $90 \%$ of the POM measured in Logy Bay. This is not consistent with other studies (Widdows et al. 1979, Soniat et al. 1984, Poulet et al. 1986), which found that the sum of these biochemical constituents accounts for no more than 10 to $15 \%$ of the POM in environments characterised by high loadings of seston originating from terrestrial sources or from resuspension of the bottom sediment, where a significant portion of the POM is likely to be refractory. In Logy Bay, however, the supply of POM primarily depends upon the phytoplankton bloom, and resuspension and terrigenous input of SPM are probably small for most of the year.

The sum of carbohydrate + lipid + protein has been termed 'food material' (FM) by some authors. Maita \& Yanada (1978) found that the 2 major components of the food material (carbohydrate + protein) occur at maximal concentrations in winter and minimal levels in summer at Funka Bay, Japan. A similar seasonal variation has been recorded by Widdows et al. (1979) for the Lynher estuary in southwest England. These observations are inconsistent with our data which are, however, in good agreement with those reported by Soniat et al. (1984) for Galveston Bay, Texas, USA, where the FM is higher during spring-summer and lower winter. The present study shows that the FM in Logy Bay reaches values as high as $700 \mu \mathrm{g} \mathrm{l}^{-1}$ during April-May, whereas values around $200 \mu \mathrm{g} \mathrm{l}^{-1}$ are more usual for the rest of the year (Fig. 7A).

Widdows et al. (1979) developed a food index based on the ratio food material to total seston. This index is based on the assumption that feeding is non-selective, so that PIM 'dilutes' the food available for filterfeeding organisms. The main peaks in the food index for Logy Bay occur during the spring-summer, with values as high as $55 \%$ (Fig. 7B). Lower values are typical of winter, when the food index drops to values below $10 \%$, indicating that the seston is of low nutritional quality. Soniat et al. (1984) also found the highest food index during spring and summer in Galveston Bay, but the value never exceeded about $11 \%$, demonstrating a nutritionally dilute environment. On the 
other hand, Widdows et al. (1979) found an inverse relationship between 'FM' and 'food index', whereby food material in the Lynher estuary is higher in winter and lower in summer, but the food index (food material expressed as a percentage of the total seston) is only $6 \%$ in winter, rising to $25 \%$ in summer. FM is diluted by PIM in the seston, but low values for the food index are not necessarily associated with a low amount of food material. Thus in Yaldad Bay, Chile, Navarro et al. (1993) recorded values for FM 4 times greater than our values for Logy Bay, whereas food index values were higher at Logy Bay than at Yaldad.

Our data suggest that the gross analysis of the seston or the measurement of a single chemical variable cannot describe fully the nutritive value of the SPM, and that a knowledge of the food material (protein + carbohydrate + lipid) as well as the food index is useful in determining the quality of the food available to suspension-feeders. Furthermore, all the indicators of seston quantity and quality consistently showed that the food supply for suspension-feeders such as Modiolus modiolus in Logy Bay was better in 1987 than in 1988, at least during the spring bloom. Such variation between years is likely to be reflected in the growth and reproduction of the suspension-feeder, as was shown by MacDonald \& Thompson (1985a) for the sea scallop Placopecten magellanicus, and should be taken into account when generalising from a set of observations made in a single year.

Acknowledgements. The authors gratefully acknowledge the valuable help of $\mathrm{E}$. Hatfield and S.-H. Lee, who carried out the biochemical analyses. The work was supported by an NSERC (Canada) operating grant to R.J.T and by a fellowship to J.M.N. from the International Development Research Centre (Canada).

\section{LITERATURE CITED}

Anderson FE (1970) The periodic cycle of particulate matter in a shallow temperate estuary. J sedim Petrol 40:1128-1135

Anderson FE, Meyer LM (1986) The interaction of tidal currents on a disturbed intertidal bottom with a resulting change in particulate matter quantity, texture and food quality. Estuar coast Shelf Sci 22:19-29

Armstrong FA (1958) Inorganic suspended matter in sea water. J mar Res 17:23-34

Barnes H, Heath JR (1966) The extraction of glycogen from marine invertebrate tissues. Helgoländer wiss Meeresunters 13:115-117

Bayne BL, Widdows J, Newell RIE (1977) Physiological measurements on estuarine bivalve molluscs in the field. In: Keegan BK, O'Ceidigh P, Boaden PJS (eds) Biology of benthic organisms. Pergamon, New York, p 57-68

Bayne BL, Hawkins AJS, Navarro E (1987) Feeding and digestion by the mussel Mytilus edulis L. (Bivalvia: Mollusca) in mixtures of silt and algal cells at low concentrations. J exp mar Biol Ecol 111:1-22
Berg JA, Newell RIE (1986) Temporal and spatial variations in the composition of seston available to the suspension feeder Crassostrea virginica. Estuar coast Shelf Sci 23: 375-386

Bock MJ, Miller DC (1994) Seston variability and daily growth in Mercenarla mercenaria on an intertidal sandflat. Mar Ecol Prog Ser 114:117-127

Cadée GC (1982) Tidal and seasonal variation in particulate and dissolved organic carbon in the Western Dutch Wadden Sea and Marsdiep tidal inlet. Neth J Sea Res 15: 497-513

Christensen H, Kanneworff E (1985) Sedimenting phytoplankton as major food source for suspension and deposit feeders in the Øresund. Ophelia 24:223-244

Conover RJ (1978) Transformation of organic matter. In: Kinne O (ed) Marine ecology, Vol. IV, Dynamics. J Wiley and Sons, Chichester, p 221-499

Dawson R, Schramm W, Bolter M (1985) Factors influencing the production, decomposition and distribution of organic and inorganic matter in Admiralty Bay, King George Island. In: Siegfried WR, Condy PR, Laws RM (eds) Antarctic nutrient cycles and food webs. Springer-Verlag, Berlin, p 109-114

Dubois M, Gilles KA, Hamilton JM, Rebers PA, Smith F (1956) Colorimetric method for the determination of sugars and related substances. Analyt Chem 28:350-356

Fegley SR, MacDonald BA, Jacobsen TR (1992) Short-term variation in the quantity and quality of seston available to benthic suspension-feeders. Estuar coast Shelf Sci 34: 393-412

Fréchette M, Bourget E (1985a) Energy flow between the pelagic and benthic zones: factors controlling particulate organic matter available to an intertidal mussel bed. Can J Fish Aquat Sci 42:1158-1165

Fréchette M, Bourget E (1985b) Food-limited growth of Mytilus edulis $\mathrm{L}$. in relation to the benthic boundary layer Can J Fish Aquat Sci 42:1166-1170

Gnaiger E (1983) Calculation of energetic and biochemical equivalents of respiratory oxygen consumption, Appendix C. In: Gnaiger E, Forstner H (eds) Polarographic oxygen sensors. Springer-Verlag, Berlin, p 337-345

Gnaiger E, Bitterlich G (1984) Proximate biochemical composition and caloric content calculated from elemental CHN analysis: a stoichiometric concept. Oecologia 62: 289-298

Gordon DC (1983) Introductory remarks, Symposium on Dynamics of Turbid Coastal Environments. Can J Fish Aquat Sci 40(Suppl):3-7

Griffiths RJ (1980) Natural food availability and assimilation in the bivalve Choromytilus meridionalis. Mar Ecol Prog Ser 3:151-156

Healey FP (1973) Inorganic nutrient uptake and deficiency in algae. CRC crit Rev Microbiol 3:69-113

Incze MI, Roman MR (1983) Carbon production and export from Biscayne Bay, Florida. II. Episodic export of organic carbon. Estuar coast Shelf Sci 17:61-72

Jørgensen CB (1975) Comparative physiology of suspension feeding. A Rev Physiol 37:57 -79

Kranck K (1980) Variability of particulate matter in a small coastal inlet. Can J Fish Aquat Sci 37:1209-1215

MacDonald BA. Thompson RJ (1985a) Influence of temperature and food availability on the ecological energetics of the giant scallop Placopecten magellanicus. 1. Growth rates of shell and somatic tissue. Mar Ecol Prog Ser 25: 279-294

MacDonald BA, Thompson RJ (1985b) Influence of temperature and food availability on the ecological energetics of 
the giant scallop Placopecten magellanicus. II. Reproductive output and total production. Mar Ecol Prog Ser 25: 295-303

Maita Y, Yanada M (1978) Particulate protein in coastal waters, with special reference to seasonal variation. Mar Biol 44:329-336

Malone TC (1981) The relative importance of nanoplankton and net plankton as primary producers in tropical, oceanic, and neritic phytoplankton communities. Limnol Oceanogr 16:633-639

Marsh JB, Weinstein DB (1966) Simple charring method for determination of lipids. J Lipid Res 7:574-576

Mayzaud P, Chanut JP, Ackman RG (1989) Seasonal changes of the biochemical composition of marine particulate matter with special reference to fatty acids and sterols. Mar Ecol Prog Ser 56:189-204

Mayzaud P, Taguchi S (1979) Size spectral and biochemical characteristics of the particulate matter in the Bedford Basin. J Fish Res Bd Can 36:211-218

Mayzaud P. Taguchi S, Laval P (1984) Seasonal patterns of seston characteristics in Bedford Basin, N.S., relative to zooplankton feeding: a multivariate approach. Limnol Oceanogr 29:745-762

Myklestad S, Haug A (1972) Production of carbohydrates by the marine diatom Chaetoceros affinis var. willei (Gran) Hustedt. I. Effect of the concentration of nutrients in the culture medium. J exp mar Biol Ecol 9:125-136

Navarro JM, Clasing $E$, Urrutia $G$, Asencio $G$, Stead $R$, Herrera C (1993) Biochemical composition and nutritive value of suspended particulate matter over a tidal flat of southern Chile. Estuar coast Shelf Sci 37:59-73

Newell RIE, Bayne BL (1980) Seasonal changes in the physiology, reproductive condition and carbohydrate content of the cockle Cardium (= Cerastoderma) edule (Bivalvia: Cardiidae) Mar Biol 56:11-19

Parsons TR, Maita Y, Lalli CM (1984) A manual of chemical and biological methods for seawater analysis. Pergamon Press Canada, Ltd, Willowdale, ONT

Parsons TR, Stephens K, Strickland JDH (1961) On the chemical composition of eleven species of marine phytoplankton. J Fish Res Bd Can 18:1001-1016

Pocklington R (1985) Organic matter in the Gulf of St. Lawrence in winter. Can J Fish Aquat Sci 42:1556-1561

Pocklington R, Leonard JD (1979) Terrigenous organic matter in sediments of the St. Lawrence Estuary and the Saguenay Fjord. J Fish Res Bd Can 36:1250-1255

Pomeroy LR, Deibel D (1986) Temperature regulation of bacterial activity during the spring bloom in Newfoundland coastal waters. Science 233:359-361

Poulet SA, Cossa D, Marty JC (1986) Combined analysis of the size spectra and biochemical composition of particles

This article was presented by J. M. Shick (Senior Editorial Advisor), Orono, Maine, USA in the St. Lawrence estuary. Mar Ecol Prog Ser 30:205-214

Reichardt W. Dieckmann G (1985) Kinetics and trophic role of bacterial degradation of macro-algae in Antarctic coastal waters. In: Siegfried WR, Condy PR, Laws RM (eds) Antarctic nutrient cycles and food webs. Springer-Verlag, Berlin, p 115-122

Russell-Hunter WD (1970) Aquatic productivity: an introduction to some basic aspects of biological oceanography and limnology. Collier-MacMillan, London

Scott JM (1980) Effect of growth rate of the food alga in the growth/ingestion efficiency of a marine herbivore. J mar biol Ass UK 60:681-702

Sheldon RW, Parsons TR (1967) A continuous size spectrum for particulate matter in the sea. J Fish Res Bd Can 24: 909-915

Soniat TM, Ray SM, Jeffrey LM (1984) Components of the seston and possible available food for oysters in Galveston Bay, Texas. Contrib Mar Sci 27:127-141

Thompson RJ (1984) The reproductive cycle and physiological ecology of the mussel Mytilus edulis in a subarctic, non-estuarine environment. Mar Biol 79:277-288

Thompson RJ, MacDonald BA (1990) The role of environmental conditions in the seasonal synthesis and utilisation of biochemical energy reserves in the giant scallop. Placopecten magellanicus. Can J Zool 68:750-756

Utermöhl H (1958) Zur Vervollkommnung der Quantitativen Phytoplankton-Methodik. Mitt int Verein theor angew Limnol 9:1-38

Vahl O (1980) Seasonal variation in seston and in the growth rate of the Iceland scallop, Chlamys islandica (O F. Müller) from Balsfjord, $70^{\circ} \mathrm{N}$. J exp mar Biol Ecol 48:195-204

Ward LG (1981) Suspended-material transport in marsh tidal channels, Kiawah Island, S.C. Mar Geol 40:139-154

Wassmann $\mathrm{P}$, Aadnesen A (1984) Hydrography, nutrients, suspended organic matter, and primary production in a shallow fjord system on the west coast of Norway. Sarsia 69:139-153

Widdows J, Fieth P, Worrall CM (1979) Relationships between seston, available food and feeding activity in the common mussel Mytilus edulis. Mar Biol 50:195-207

Wilkinson L (1988) SYSTAT: the system for statistics. SYSTAT Inc, Evanston, IL

Worrall CM, Widdows J, Lowe DM (1983) Physiological ecology of three populations of the bivalve Scrobicularia plana. Mar Ecol Prog Ser 12:267-279

Yentsch CS, Menzel DW (1963) A method for the determination of phytoplankton chlorophyll and pheophytin by fluorescence. Deep Sea Res 10:221-231

Zeitzschel B (1970) The quantity, composition and distribution of suspended particulate matter in the Gulf of California. Mar Biol 7:305-318

Manuscript first received: October 12, 1992

Revised version accepted: April 1, 1995 